\title{
Biodiversity of wine grapes: less than we thought
}

\author{
This article was published in the following Dove Press journal: \\ International Journal of Wine Research \\ I July 201 I \\ Number of times this article has been viewed
}

\section{Roger M Pinder \\ International Journal of Wine Research, York, UK}

Correspondence: Roger M Pinder 2 St Wilfrid's Court, Monkgate, York YO3I 7UQ, UK Tel +441904646684

Email roger.pinder@gmail.com
The Editor of the International Journal of Wine Research has had a long-standing interest in the genetics of wine grape varieties. ${ }^{1}$ Two publications, in particular, piqued the interest from both the scientific and consumer point of view. Cabernet Sauvignon is the offspring of a chance cross-pollination of Sauvignon Blanc and Cabernet Franc in western France several centuries ago. ${ }^{2}$ Similarly, virtually all of the varieties from north-eastern France, including such luminaries as Chardonnay, lesser lights like Gamay Noir and Aligoté, but also Melon de Bourgogne, Auxerrois, and several others were the offspring of two parents, Pinot, probably Pinot Noir for many varieties, and Gouais Blanc. ${ }^{3}$ Syrah is also the chance offspring of two obscure grapes from southeastern France, the red Dureza and the white Mondeuse Blanche. ${ }^{4}$ This suggests that some of the classic grape varieties which wine drinkers hold in high regard-Cabernet Sauvignon, ${ }^{2}$ Chardonnay, ${ }^{3}$ and Syrah ${ }^{4}$ - are in fact genetically modified organisms (GMOs) formed by natural hybridization. Despite the unfavorable light in which many consumers and even governments view GMOs, particularly in the European Union, several popular and esteemed wine grape varieties had already undergone substantial genetic modification long before the dawn of the modern biotechnology era.

The general impression has been that there are a lot of different wine grape varieties and therefore it follows that there is also extensive biodiversity. However, a new and comprehensive publication on grape genetics ${ }^{5}$ has suggested that this is much less than we thought. Inbreeding seems to have limited wine grapes to a relatively small number of varieties sharing many incestuous relationships. It appears that up to $75 \%$ of the 950 Vitis vinifera and 59 Vitis sylvestris varieties included in this study, utilizing molecular markers to identify the DNA of grapes from their leaves, have direct family connections with each other either as parents, siblings, or offspring. Cabernet Franc and Sauvignon Blanc were confirmed as the parents of Cabernet Sauvignon, but both Sauvignon Blanc and Pinot Noir are progeny of Traminer which seems to be the head of a large and interconnected family and sits like a spider at the centre of a vast web. Traminer has 20 first-degree relatives, and is believed to be an ancient cultivar widely used during the history of grape breeding. Sauvignon Blanc and Chenin Blanc are identified for the first time as siblings, and they share a parent in Traminer. Furthermore, two of the most common Rhône varieties, Syrah for red wine and Viognier for white, also seem to be siblings.

A large proportion (58\%) of Vitis vinifera wine grapes in the study showed evidence of cloning. Pinot, for example, has been extensively cloned into diverse phenotypes, 
such as the lighter berry color of Pinot Blanc and Pinot Gris as well as the darker Pinot Meunier and Pinot Noir. The authors attribute the inbreeding to the adoption over the centuries of vegetative propagation methods for grape breeding such as grafting and the planting of shoots. This has been a doubleedged sword, on the one hand providing a benefit by ensuring true breeding cultivars and on the other discouraging the generation of unique cultivars through deliberate crosses. Other factors contributing to the relatively small number of cultivars in use today include the devastation caused in the past by vine diseases like phylloxera and mildew as well as the more recent development of the global wine industry.

Does this lack of diversity matter for the future of wine grapes? It does because the grape currently faces severe pressure from an array of pathogens, making the long-term sustainability of the wine industry reliant on exploitation of the grape's tremendous natural genetic diversity. Wine grape vines are often intensively treated with chemicals to deal with pathogens, except for those grown by organic, biodynamic, or natural methods. So far, while substantial genetic diversity has been maintained since domestication of Vitis vinifera about 7000 years ago, there has been very limited exploration of this diversity. Rather, grape vines are all part of an extended pedigree. Myles and his colleagues ${ }^{5}$ have suggested that the genetic molecular markers developed in their study can be used to defend against the pathogenic threat, by replacing the current laborious procedures of selectively breeding thousands of seedlings in search of the most resistant vines. Genomic selection could be used in an earlier phase of seedling growth, thereby accelerating the identification of the most pathogen-resistant vines at considerable lower cost. The wine industry has in recent years polished its green credentials by using fewer chemicals and more environmentally-friendly production methods such as New Zealand's carbon-neutral scheme. It probably needs to grasp the nettle of genetic diversity and tap into the world's germplasm collections to generate improved cultivars which will be more resistant to pathogens and perhaps even to climate change. Meredith ${ }^{6}$ had pointed out in a seminal review a decade ago that targeted genetic modification of existing classic cultivars was already possible and could reduce disease loss and pesticide usage without otherwise altering their wine attributes. Not much has changed in the world of wine since then. But the big question remains on the table - are the world's wine makers, wine drinkers and, perhaps more importantly, wine regulators ready for such innovation?

\section{References}

1. Pinder RM, Meredith CP. The identity and parentage of wine grapes. In: Sandler M, Pinder RM, editors. Wine: a scientific exploration. London, UK: Taylor \& Francis; 2003:260-273.

2. Bowers JE, Meredith CP. The parentage of a classic wine grape, Cabernet Sauvignon. Nat Genet. 1997;16(1):84-87.

3. Bowers JE, Boursiquot JM, This P, Chu K, Johansson H, Meredith C. Historical genetics: the parentage of Chardonnay, Gamay, and other wine grapes of north-eastern France. Science. 1999;285(5433):1562-1565.

4. Meredith CP, Bowers JE, Riaz S, Handley V, Bandman EB, Dangl GS. The identity and parentage of the variety known in California as Petite Sirah. Am J Enol Vitic. 1999;50(3):236-242.

5. Myles S, Boyko AR, Owens CL, et al. Genetic structure and domestication history of the grape. Proc Natl Acad Sci U S A. 2011;108(9): $3530-3535$.

6. Meredith CP. Grapevine genetics: probing the past and facing the future. Agric Conspec Sci. 2001;66(1):21-25.
International Journal of Wine Research

\section{Publish your work in this journal}

The International Journal of Wine Research is an international, peer-reviewed open-access, online journal focusing on all scientific aspects of wine, including: vine growing; wine elaboration; human interaction with wine; and health aspects of wine. The journal provides an open access platform for the reporting

\section{Dovepress}

of evidence based studies on these topics. The manuscript management system is completely online and includes a very quick and fair peer-review system, which is all easy to use. Visit http://www.dovepress.com/testimonials.php to read real quotes from some of our published authors. 